University of Nebraska - Lincoln

DigitalCommons@University of Nebraska - Lincoln

Faculty Publications -- Department of English

English, Department of

Summer 2007

\title{
Faulkner in the Fifties: The Making of the Faulkner Canon
}

Roland K. Végső

University of Nebraska - Lincoln, rvegso2@unl.edu

Follow this and additional works at: https://digitalcommons.unl.edu/englishfacpubs

Part of the American Literature Commons, Intellectual History Commons, and the Modern Literature Commons

Végső, Roland K., "Faulkner in the Fifties: The Making of the Faulkner Canon" (2007). Faculty Publications -- Department of English. 96.

https://digitalcommons.unl.edu/englishfacpubs/96

This Article is brought to you for free and open access by the English, Department of at DigitalCommons@University of Nebraska - Lincoln. It has been accepted for inclusion in Faculty Publications -- Department of English by an authorized administrator of DigitalCommons@University of Nebraska - Lincoln. 


\title{
Faulkner in the Fifties: The Making of the Faulkner Canon
}

\begin{abstract}
S MANy COMMENTATORS OF THE PERIOD noted, one A of the most significant events of early post-war literary culture in the United States was William Faulkner's sudden rise to international fame. The most extensive investigation of this dramatic revaluation of cultural status was carried out by Lawrence D. Schwartz in his Creating Faulkner's Reputation: The Politics of Modern Literary Criticism. ${ }^{1}$ Schwartz examines in detail the cultural and political processes that led to Faulkner's discovery in the I940s after the primarily negative reception of his works in the I93os by leftist critics. He argues that Faulkner's entry into the canon was dependent on the early Cold War cultural context which, in terms of available critical discourses, is defined by him as a liberal consensus between the New Critics and the New York intellectuals. According to Schwartz, Faulkner emerges as the common denominator of this consensus-backed by the Rockefeller Foundation and the State Department.

Still following Schwartz, we have to take into consideration both the political and the aesthetic aspects of this consensus. Concerning the political complications, Schwartz writes: "The reconciliation of conservative New Critics and radical New York intellectuals was one of the paradoxes of the Cold War" (74). Both of the parties involved had to reformulate their pre-war politics during the I940s to meet the demands of the new situation. The New Critics had to abandon their anti-modern, regionalist Agrarian conservatism; while the New York intellectuals had to compromise their leftist radicalism to articulate an unequivocally anti-Communist liberalism. On the level of aesthetics,
\end{abstract}


as a correlative of their politics, the opposition between the two camps was formulated in terms of the tension between aesthetic formalism and literature of social commitment. The basis of the compromise is the consolidation of formal innovation and radical politics. In the postwar context, "literary radicalism" is not progressive political action but formal innovation.

While Schwartz's arguments are indispensable for our understanding of Faulkner's significance for American literature, quite significantly, he only raises the question of Faulkner's canonization and never really addresses the complications of the Faulkner canon itself. My thesis, then, is that the real substance of the critical consensus outlined by Schwartz is precisely the Faulkner canon, which therefore emerges as the very condition of Faulkner's canonization within American literature in the first place. As a first step, by introducing a set of distinctions, Faulkner had to be divided in order to turn his work into a legitimate reading material, the unity of which could then be posed as a critical problem. The debate concerning the rift between an early and a late Faulkner - "the two-Faulkner theory" (Polk 302) — still forms an integral part of Faulkner studies precisely because it is an unavoidable confrontation with the very conditions of Faulkner's canonization. Without the recognition of an irreconcilable conflict between a plurality of Faulkners, there would be no "Faulkner" at all. The question is, how do we decide to manage this plurality?

A brief survey of the history of Faulkner criticism makes it sufficiently clear that by now we can speak of at least two foundational critical moments. The first, what we could call "the modernist consensus," was responsible for Faulkner's discovery in the late forties. It defined Faulkner as a major modernist formal innovator and a representative of the moderate political orientation of the Cold War liberal consensus (based on the renunciation of all forms of political extremism). As I will try to show here, this consensus was fully dependent on the category of the "late phase." The main objective of the "postmodern consensus," however, was to maintain Faulkner at the center of the canon by redefining him as a postmodern rather than a modernist author. The postmodern turn in Faulkner studies employed two major strategies. It either rediscovered the major works as postmodern novels avant la lettre or tried to identify in Faulkner a tendency towards a nascent postmodernism, most often in the late works. ${ }^{2}$ We can see that in spite of their 
differences, the category of the late phase remained an essential critical tool for both generations.

Let me recall here that it appears to be a well-known fact among the international literati that not all of Faulkner's works are really "that great." The vexing presence of this "other Faulkner" has been a nuisance for Faulkner criticism from the very beginning. For example, Michael Millgate, assessing the critical heritage at a historical juncture, comments:

Bleikasten ... speaks of the international Faulkner canon as currently comprised of The Sound and the Fury, As I Lay Dying, Sanctuary, Light in August, Absalom, Absalom!, and The Wild Palms. The American Faulkner canon, I suspect, would add Go Down, Moses certainly and The Hamlet probably, hesitate over Sanctuary, and make the serious mistake of relegating The Wild Palms to the minors. (William Faulkner 39)

Both of the most important principles of Faulkner's canonization are clearly legible here: on the one hand, there is the basic separation of high art from lower achievements; on the other hand, a certain periodization is also at work. All of the works named by Millgate are from the period 1929-1942. That is, the products of Faulkner's last decade are excluded from both of these canons. At the same time, within this major period, as the cases of Sanctuary and Wild Palms show, there exists an opposition of modernist masterpieces and works of more popular appeal. While the international canon is seemingly more willing to consider the lesser works as great literature, even in this case it is the periodization of Faulkner's oeuvre that provides the primary terrain within which the great works should be separated from the weak ones. For example, when James E. Carothers warns us that "however long or short one reckons the late period to have been, what does seem clear is that it can't, or shouldn't, be treated as monolithic, generalized into a consistency it does not in fact possesses" (273), he calls attention to the primacy of the periodization over the aesthetic value judgments, since the latter by definition cannot be applied to the excluded period. By today's standards, of course, the boundaries separating high art from popular culture are much more problematic than they appeared to be in the fifties, so for us it is the persistence of the periodization that should be posed as the critical problem. 
From a historical perspective, the separate emergence of these the two different principles of canonization can be discussed in quite precise terms. While the tension between high art and popular culture was already an integral part of Faulkner criticism in the 1930s, the issue of periodization is primarily a fifties phenomenon. In an attempt to complicate the accepted narratives of Faulkner's early literary reputation (as, for example, represented by Schwartz), D. Matthew Ramsey argues for the significance of Sanctuary in establishing Faulkner as a great American novelist:

Contemporary evidence, then, indicates that the reputation of both Faulkner and Sanctuary were, in I93 I, much more nuanced than the usual narrative of Faulkner's literary career and that the gap between American literature and its public readership was very much on the minds of Faulkner's contemporaries. Could a bestseller of such "disrepute" also be great American literature? Critics of the time thought so, though this understanding of the novel is largely forgotten. (13)

In other words, Faulkner's discovery in the mid-I940s was preceded by an earlier attempt at canonization that aimed to unite the popular and the artistic. The failure of this attempt to establish a comprehensive critical consensus, however, is obvious in light of the developments in Faulkner criticism after WWII. While the tension between low and high art remained an essential structuring force of criticism, it had to be complemented by the rhetoric of periodization in order to establish the general critical consensus concerning Faulkner's position in the literary canon. Without this periodized canon, Faulkner could not have become the unequivocal center of American literature. As a matter of fact, the invention of the Faulkner canon in the late forties served precisely the purpose of deleting the terms of this earlier canonization. In the fifties, Faulkner had to be construed as high art and not as popular literature.

Since until the late thirties Faulkner's reception was primarily restricted to reviews of the latest works, due to the very nature of the review essay, critics tended to concentrate on individual works. ${ }^{3}$ Therefore, the issue of periodization is for the most part absent in their responses. It is true that these reviewers identified differences between the already published works, but their conclusive judgments tended 
to look to the future, anticipating the fate of a more or less talented young writer, rather than to the past in order to identify separate units in Faulkner's still relatively short career. The central issue of this early criticism was the separation of the true artist from the hack in pursuit of cheap ideas and mere sensationalism. With the first appearance of more extensive critical studies like Aubrey Starke's article in I934 and Conrad Aiken's and George Marion O'Donnell's now classic articles in 1939, the discussion of Faulkner as a whole has been established. It is in wake of this invention of "Faulkner as a whole" that the first signs of periodization appeared in the I940s. For example, Malcolm Cowley, in an article published in I945, spoke of mistakenly "overpraised" early novels and "unjustly neglected" later works. In other words, the discovery of the unity of the Yoknapatawpha saga initiated a rhetoric of periodization as well. At the same time, the discovery of greatness almost automatically led to the necessary closure of a period. Quite significantly, the most explicit example of this move also stems from I945, when John Miller Maclachlan already speculated that Faulkner's major artistic output is already behind him ( $\left.{ }^{6} 67\right)$. Thus we can see that by the mid-forties the general outlines of the Faulkner canon were becoming clearly visible. The most important point, however, is that the discovery of the thematic unity of the Yoknapatawpha saga roughly coincides with the simultaneous establishment of the "major phase" (Cowley's "later novels") and its end.

Faulkner's late-modernist "ideological mainstreaming" (Polk 300) in the fifties was responsible not only for the making of his reputation, it also meant the creation of a certain kind of Faulkner useful for particular ideological purposes. Nothing is more revealing with regard to this ideological work than the fact that the making of Faulkner's reputation coincides with the creation of a Faulkner canon (or the Faulkner canon as we know it) based on the periodization of his oeuvre. Putting aside problems of exact dating, this periodization usually divides the writer's career into three units which have their corresponding aesthetic values: the years of apprenticeship (the I920s); the major years (1929-1936/40/42/46-sometimes divided into smaller units); and the late Faulkner (1948-1962). As the argument goes, the early Faulkner was not yet fully in control of his artistic powers, while the late Faulkner was already past his prime. ${ }^{4}$ This late period is usually condemned for 
its didactic moralizing, abstract oversimplifications, rhetorical excesses, and its repetitious nature (which was understood to be the exhaustion of the author's imagination). The most striking feature of Faulkner's reception in the fifties, however, is that the self-assured praise of the recently discovered American genius goes hand-in-hand with the deprecation of the recent works: in a certain sense, Faulkner's canonization coincides with his exclusion from his own canon, as well as the canon of American literature. Two important things should be pointed out in this context: first, the canonization occurs simultaneously with the periodization of the oeuvre; second, the moment of this canonization happens to coincide with the end of the "major period" and the beginning of the "late phase." In other words, the periods of Faulkner's career are separated precisely at the moment when the "major period" is simultaneously acknowledged and announced to be over. Although it might seem somewhat contradictory, we have to consider the possibility that the creation of the critical category of the inferior late phase is actually the precondition of Faulkner's modernist canonization rather than being an obstacle to it or being simply one of its consequences.

Obviously, these complications call attention to the fact that "Faulkner's late style," unlike the early period or the major phase, is not a retrospective category created in tranquil recollection after the closure of the oeuvre-it was created while the oeuvre was still in progress. William Van O'Connor, the author of one of the most popular books on Faulkner in the fifties, illustrates this point perfectly when he writes: "The Faulkner canon divides into three periods, certain themes, techniques, and mannerisms being common to all of them" ( 160$)$. For O'Connor, writing in I954, the beginning of the late period is I940, the publication of The Hamlet. Discussing the "failure or relative failure" of Requiem for a Nun, he expresses his doubts about Faulkner's latest works and wonders "whether another of Faulkner's works, his socalled magnum opus, will be on the level of some of his earlier work" (159). What is striking about these judgments is that the last novel Van O'Connor discusses in his book, Requiem for a Nun, is from I95I, what we would consider today as the beginning of the late phase. Nevertheless, at the same time as its existence is established, the value of the whole late phase is also declared.

If we consider the period marked by Cowley's The Portable Faulkner (I946) and the monographs published shortly after Faulkner's death 
(1962) - that is, the period of Faulkner criticism that roughly coincides with the "late phase" and the final closure of the oeuvre-we find that the periodized canon, in spite of the factional differences among critics, is virtually omnipresent. ${ }^{5}$ Even if critics disagree about the reasons for the decline of Faulkner's artistic powers, the existence of the periods is never questioned. Therefore, it is safe to assume that the periodized canon emerged during this period as the most important prop of the critical consensus outlined by Schwartz. The consensual framework of the critical agreement between the New Critics and the New York intellectuals appears to have been the tacit agreement that the oeuvre can and should be periodized on the basis of aesthetic values. In this sense, it was the formation of the "late phase" that made the consensus possible in the first place. The essence of this consensus was that, based on the separation of the different periods, the canonization of the neglected genius needs to make room for contradictory judgments: Faulkner can be a nihilist and a moralist, a regionalist and a conveyor of universal values-or, in terms of basic value judgments, great and terrible at the same time. ${ }^{6}$ Quite significantly, even Faulkner's laudatory early reception was much more willing to articulate frank dissatisfaction with the writer than the kind of institutionalized Faulkner industry that grew up in its wake. Cowley articulates this complication with acerbic simplicity: "It had better be admitted that almost all his novels have some obvious weakness in structure" (xxiv). Although most of Faulkner's sympathetic readers probably would have tamed the embarrassing implications of this disturbing generalization (some of Faulkner's works are faulted but by no means "almost all"), the dissatisfaction formulated here is one of the most persistent themes of Faulkner's early reception. We can see why Cowley's judgment is thus a privileged locale of the liberal consensus: at its most critical extreme, it presents Faulkner as the "Genius without a Masterpiece," but at the same time it gives way to the compromise that allows different and even contradictory value judgments to inhabit the same oeuvre.

As is well known, the first major step towards Faulkner's favorable critical reception was the perception of a mythical, symbolic unity within the Yoknapatawpha saga, which allowed Faulkner to break out of the rather restrictive category of an obscure regionalist and attain the privilege of being the communicator of more universal themes. The significance of Cowley's The Portable Faulkner in establishing both 
Faulkner's position in the canon and the Faulkner canon itself is a widely recognized fact. Let me recall here the famous statement from the revised version of the foreword: "I respect the later Faulkner, with most of his demons exorcised, but the younger possessed and unregenerate author is the one whose works amaze us, as they never ceased to puzzle and amaze himself" (xxxi). Cowley's language suggests that Faulkner himself would testify (through his endless self-amazement) to the correctness of the formation of the Faulkner canon based on this simple periodization. But strangely enough, this discontinuity within the canon is used to establish an organic unity within the oeuvre itself. In another often quoted passage of the introduction, Cowley celebrated "the whole interconnected pattern" of the Yoknapatawpha cycle in the following terms: "There in Oxford, Faulkner performed a labor of imagination that has not been equaled in our time and a double labor: first, to invent a Mississippi county that was like a mythical kingdom, but was complete and living in all its details; second, to make his story of Yoknapatawpha County stand as a parable or legend of all the Deep South" (viii). Later he adds: "It is this pattern, and not the printed volumes in which part of it is recorded, that is Faulkner's real achievement" (xv, emphasis added). This is indeed a strange celebration of a literary genius: the works themselves produced by the author are but weak imitations of the idea which is "the real achievement." The reason why the pattern had to be emphasized over the works themselves was the need for unity (something "complete and living"), since Faulkner's works contained something disturbing that could not be integrated into a homogenous pattern, something that disturbed the unity: "As one book leads into another, Faulkner sometimes falls into inconsistencies of detail” (98). Although still somewhat cautious, Cowley did try to find an explanation for this inconsistency: "I should judge that most of them are afterthoughts rather than oversights" (99). To put it differently, the formal challenges of the individual works were displaced by Cowley to the abstract conceptual unity of the oeuvre.

In order to illustrate the dependence of Schwartz's thesis on this periodization, I will briefly highlight the moment of periodization in some of the most influential early pieces of Faulkner criticism. To do so, I will refer to Michael Millgate's first book on Faulkner (published in I96I) as he closes his investigations with a brief and rather dismissive survey of Faulkner criticism. In the concluding chapter of the book, 
Millgate complains about the inadequacies of this criticism in the following terms:

Only recently has it become thoroughly respectable to speak of William Faulkner as a great novelist, and there are still those ready to declare that he is, in the accepted sense of the word, scarcely a novelist at all. From the very first, critical writing about Faulkner has been sharply divisible into the adulatory and the dismissive, and the balanced middle view, which perceives in his work a greatness transcending all faults and limitations, has too rarely been heard. (William Faulkner ıо3)

The opening sentence of the passage calls attention to the troubled canonization that had to proceed by the paradoxical consensus of the "Genius without a Masterpiece." Although Faulkner was already a "respectable" topic for literary criticism, certain critics still moved within the paradigm that predated his canonization and simply attacked him for formal inconsistencies. Millgate, on the other hand, advocates here the reading that made Faulkner's canonization possible in the first place: one must read Faulkner simultaneously as a "great novelist" and as "scarcely a novelist at all." As the second sentence of the quotation makes clear, the real problem is the absolute separation of the two extremes of critical positions (uncritical celebration and overhasty dismissal). Millgate's solution is the "balanced middle view"- the perfect locale of a liberal consensus - which allows the reader to locate greatness in a sphere that transcends faults and limitations. At the very end of his book, however, Millgate formulates this consensus in explicitly formalist terms: "There has been quite enough discussion of his social and political attitudes, which are not in themselves particularly original or exciting, and the great need now is for extended and detailed examination of the writing itself, its language, syntax, imagery, and rhythmic patterns" (I I3). On the one hand, this program is the direct anticipation of the kind of institutionalization that was most excellently embodied in Cleanth Brooks' William Faulkner: The Yoknapatawpha Country ( 1963 ). On the other hand, it is a direct suspension of value judgments, since it already takes "greatness" for granted and designates the role of the critic as the explicator of textual and linguistic complexities.

After dismissing most of the Faulkner criticism of the I950s as "not of major importance" (William Faulkner I ı), Millgate singles out two 
works worthy of his readers' attention: Irving Howe's William Faulkner: A Critical Study and Olga W. Vickery's The Novels of William Faulkner. The reference to these two critics makes it easy to relate Millgate to the critical consensus between the New York intellectuals and the New Critics. The symmetry of Millgate's preferences should not be underestimated. Howe is a socially oriented critic, while Vickery is a formalist. Inasmuch as Millgate articulates an equivalence between the two, he is formulating the missing "middle way" as the critical consensus described by Schwartz. In what follows, I will discuss certain aspects of the two works to show the extent to which both sides of this critical consensus are dependent on the periodized canonization.

Howe's book is the most important synthesis of Faulkner's oeuvre to come from a New York intellectual. This monograph was first published in I95 I and then revised in 1962. The revised version still does not contain The Reivers and speaks on a number of occasions of the necessarily tentative nature of the judgments passed on an oeuvre still in progress. The first half of the book is a general assessment of Faulkner based on the social "background" of the writer where Howe singles out Faulkner's presentation of African American characters as carrying exemplary value in understanding the author's moral plight. The second half of the book is a consideration of Faulkner's achievement through readings of the most important novels.

As a preface to his brief dismissal of Requiem for a Nun, Howe comments on the general problems with Faulkner's recent works (I03-4). He speculates on the failure of Faulkner's late period by first putting the progression of the oeuvre within a "historical" framework. Howe's first reason for the shortcomings is that, as a part of its natural forward movement, Faulkner's chronicle reached the present day and, since Faulkner is essentially a Manichean mind, the blandness of present-day America simply does not provide sufficient raw material for his genius. The implication is that while in the past (during the thirties) Faulkner was writing about the past with remarkable success, the present (the fifties) fails him as a subject matter, so he fails in the present as an artist. That is to say, not only is the proper material for Faulkner the past, his very greatness is in the past itself-he is great to the extent that he belongs to the past. We can recognize here the strange double movement of canonization I pointed out earlier: Faulkner's canonization coincides with his exclusion from his own canon as well as the canon-he is con- 
strued as classic, not as contemporary literature. Indeed, if we consider the fact that during the thirties Faulkner was dismissed by most critics and that during the fifties, when his works from the thirties were discovered, his writings were considered to be weak imitations of the major period, we can see that Faulkner was never really a "contemporary" for American literature since his contemporary works were always outside the canon. If we describe this shift in Faulkner's career as "a turn from a modernist aesthetic to an aesthetic of engagement" (Dimitri I 2), quite paradoxically, Faulkner emerges as a writer who in the thirties was more of a writer for the fifties, while in the fifties he was closer to the aesthetic ideal of the thirties.

But Howe's second reason for Faulkner's artistic failure is even more important: it is his canonization itself. The interesting point about this rather widely accepted thesis is that it reverses the terms of my argument, since it can only imagine the late phase as a consequence rather than a condition of Faulkner's canonization:

What makes this problem especially acute for Faulkner is that, either through the influence of his critics or his growing selfconsciousness as a famous writer, he has felt obliged to become a semi-official historian for his imaginary world, rather than the brilliant fantast and grotesque painter that he showed himself to be in his best work. This impulse toward soberly filling in the nooks and crannies of his saga has led him to return, often unsuccessfully, to characters from his earlier novels and has also led him, still more unhappily, to indulge his taste for heady abstraction and grand pronouncements. Shamefully undervalued in the thirties, when he was making major contributions to world literature, Faulkner has been treated in the fifties a little too much like an established institution. As a result, not enough attention has been paid to the evidence that he has reached a serious impasse in his career and that the more he keeps assuring us that man will "endure," the less assurance his own work shows. (IO3-4)

Since Howe explicitly blames Faulkner's canonization for the decline of the quality of his later works, he provides a possible explanation for the reason why the canonization coincides with the beginning of the late phase. His indictment echoes the most common objections to the 
late period: it lacks the power and vitality of the major period due to its mechanically repetitive nature and the consequent tendency towards abstractions and "grand pronouncements." What needs to be further explained in this passage, however, is the claim that the critical response to Faulkner in the fifties was purely laudatory: this celebration was only directed at the works of the thirties. While Faulkner is no doubt treated as an institution, it is precisely the renunciation of the late style that ties Howe to the critical consensus of the fifties. Although he appears to be formulating a critique of recent Faulkner criticism, Howe merely joins the chorus and paves the way for the kind of response to Faulkner that he seems to be renouncing (a celebratory formalism that bypasses value judgments).

The other work singled out by Millgate for critical praise was Olga Vickery's The Novels of William Faulkner. Commenting on Vickery, Millgate writes:

It is not at all an easy book to read, and it is not, in the full sense, a critical work-Mrs. Vickery passes no judgments on the books with which she deals-but it offers cogent and extremely thorough explications of the meaning and thematic structure of each of the novels in turn. Because the book is not concerned with value-judgments, it gives almost as much attention to Faulkner's "minor" works as to those usually considered major, and such books as Pylon and even Mosquitoes emerge more interestingly from this detailed treatment than from the more cursory discussions of earlier critics. (William Faulkner i I I)

It is important to note that Millgate's next book, The Achievement of William Faulkner (1963), performs precisely this same move: it becomes an analysis of the complete oeuvre proceeding from work to work with rather suppressed value judgments. Consequently, it abandons the belligerent tone of the earlier work, which demanded a confrontation with Faulkner's obvious failures and adopts a much more reverent attitude towards a few of the novels so categorically dismissed in the first book. In a sense, one can witness here the influence of the suspension of judgment Millgate identifies in Vickery. As we have seen, Millgate's earlier book called for a double project: a formalist reading of Faulkner capable of critiquing the shortcomings of the late period. As opposed to this 
double imperative, Vickery's book is based on an exclusive adherence to the first demand (formalist reading) at the expense of the critical attitude. ${ }^{7}$

This suspension of judgment, however, is much more problematic than Millgate would let us know. First of all, it needs to be acknowledged that the whole of Vickery's project is one single value judgment: "Faulkner is great." Granted, Vickery rarely concerns herself with the kind of explicit evaluations that characterize Millgate's first book, and her readings of the "minor works" deliberately go against the grain, but her general project is still informed by the evaluative framework that made Faulkner's canonization possible. One needs only to look at the table of contents to identify the general structure of the evaluative canonization. The book is composed of three parts that correspond with Faulkner's three phases (although Vickery herself does not make this connection): the first section of the book, which does contain explicit value judgments, is devoted to the early novels; the second section is called "The Achievement of Form" and discusses the so-called "major works," The Sound and the Fury, As I Lay Dying, Light in August, and Absalom, Absalom!; the third section is called "The Pursuit of Themes" and is devoted to the rest of the oeuvre, the lesser novels which also happen to be primarily the later novels. At best, Vickery transforms the majority of the value judgments that account for the periodizing canonization into formal distinctions. Instead of a simple lack of judgment, we have here a universal framework of constantly recreated literary value (the preliminary judgment that Faulkner is great), in which formalist judgments obscure the problems of the minor works since, if the grand pattern is predicated upon the complete interdependence of every single work, the weight of the major works lends gravity to the minor ones. Nevertheless, this formalist totalization is based on value judgments on at least two levels: on the one hand, we have the judgment that Faulkner as such represents literary value; on the other hand, we have the troubled and quite often obscured judgment concerning the minor works.

But the real significance of Vickery's "non-judgmental" formalist study is that, through this displacement, it formulates a critique of Cowley's canonizing reading of Faulkner. Vickery effectively displaces the unity of pattern from the unity of Yoknapatawpha onto the unity of technique and theme (primarily through recurrent formal and struc- 
tural patterns). This shift allows her to bypass Cowley's comment concerning the structural inadequacies of almost all of Faulkner's works by simply claiming that Cowley misses the whole point of Faulkner's art (306). The basis of the critical response devoid of value judgments is precisely the fact that by the late $\mathrm{I} 95 \mathrm{O}$ it was possible to take Faulkner's greatness for granted. We witness here an effect of the critical consensus that was responsible for Faulkner's canonization: greatness finally overshadows the shortcomings. Or to put it differently, one of the more important effects of Faulkner's formalist institutionalization was that, since his greatness was taken for granted (unlike in the mid-forties when Cowley had to make a case for reading Faulkner at all), while the critical apparatus still worked within the same matrix that sanctioned the canonization, the question of value was replaced by that of form. Faulkner's shortcomings were either explained away through references to the major works or simply dismissed from the critical field. Thus, between the publication of Cowley's The Portable Faulkner in 1946 and Vickery's book in 1959, an essential step in Faulkner's canonization was completed: while Cowley's thematic unity could only canonize the Yoknapatawpha novels, formal unity could now legitimize practically anything written by Faulkner.

At the same time, however, we can also perceive here a very important internal tension of the New Critical canonization. While it is made possible by the periodized canon, the formalist totalization tends to suspend the problem of the canon by reference to the internal intertextuality of the oeuvre. There is a conflict here between trying to justify a purely formal reading extended to the whole oeuvre and the continuous maintenance of the periodized canon which made Faulkner's reputation possible in the first place. As we have seen in Cowley's case, this intertextuality is simultaneously the guarantee of the unity of the Yoknapatawpha saga and the hotbed of structural failure since it leads to inconsistencies. But when Vickery displaces the unity of the oeuvre from the unity of theme to the unity of recurrent formal patterns, it becomes apparent that there is no longer any need to exclude anything from this unity. It is enough to relegate these works to a secondary status. We have also seen, however, that while Vickery is capable of suspending judgment and providing a reading of the whole oeuvre, her reading is still implicitly informed by the periodization it claims to move beyond. More recently, the issue was addressed by Millgate in the 
following terms: "But Faulkner's deliberate use of recurrent characters, locations, and situations seems a way of insisting that in reading any one of his novels we take consciously into account, first, a set of specifically linked novels and stories and, secondly—at any rate potentially—the entire corpus of his published works" (Faulkner's Place 67). As it turns out, formalist totalization is not simply a matter of philological honesty, but a structural necessity. When one reads Faulkner, one must read the whole of Faulkner, a "whole" that, according to New Critics, was also an "organic unity." Hence the irresolvable internal contradiction of early Faulkner criticism: with its concept of unity, it was working against the very condition of Faulkner's canonization which was precisely the critical perception of the lack of unity. In other words, the internal contradiction of New Critical readings is that they have to cover over the very condition of Faulkner's canonization, since they work with the concept of an "organic unity" that they cannot fully formalize.

The making of Faulkner's modernist reputation thus proceeds through three major steps. First, we have a general condemnation of Faulkner that, in spite of the factional differences, is grounded in the assumption that the name "Faulkner" designates a unified entity which as such is relegated to the level of a second-class writer. By the mid-forties, however-and this is the crucial second step, based primarily on Cowley's reading - the rhetoric of Faulkner criticism breaks with the concept of a unified corpus. The New Critical impetus is based on an almost paradoxical recasting of the meaning of the name "Faulkner": on the thematic level, the "mythical unity" of the oeuvre (the Yoknapatawpha saga) guarantees artistic merit, while on the textual level, the disunity of the oeuvre (the structural failure of every single novel and the separation of early and later works) undermines aesthetic value. The rift thus introduced to the Faulkner oeuvre initiates a canonization according to two alternative logics: on the one hand, the novels that contribute to the mythical unity-that is, the Yoknapatawpha novelsare great; on the other hand, the later novels no longer display the initial artistic intensity that characterized the earlier works. This preliminary creation of the Faulkner canon, which is the foundation of the critical consensus of the I950s, is the necessary condition of Faulkner's canonization. In other words, while "Faulkner" as a unified entity could not have been canonized at all, by the end of the fifties (somewhat in the manner of covering up the traces of his very canonization) the 
already canonized Faulkner reclaims some of this lost unity. The third step in the history of this critical reception, although based on the disunity of the oeuvre, consists of a unified celebration of "Faulkner" as the greatest American novelist of the century which, potentially at least, leans towards the elimination of the problem of the canon. The gradual elimination of the canon, however, is not complete and the conflict between Faulkner's unqualified "greatness" and the rhetoric of periodization keeps haunting Faulkner criticism. During the third phase, the issue of the Faulkner canon is removed from the center of critical attention by two strategies: either by completely dismissing the problem of the question of value in an objective structural/formal analysis (Vickery) and raising the problem of the complete intertextuality of the oeuvre (Millgate), or by simply concentrating on the "great works" and leaving the issue of the lesser works untheorized (Brooks).

Furthermore, as I would like to argue, it was precisely the abovedescribed contradiction at the heart of New Critical readings that provided the opening through which the next generation of scholars could enter the stage of Faulkner criticism. This generation, whose theoretical and political interests could no longer be contained within the confines of the modernist consensus, did not fully emerge until the mid-seventies. ${ }^{8}$ As diverse as this group was, however, what bound them together was a more or less explicit opposition to the terms of Faulkner's modernist canonization. In a certain sense, their work was a reflection within Faulkner studies of the general transformation of the American university as it came into contact with new (mostly French) theoretical schools of thought. By the mid-eighties, however, in the wake of the pioneering works of these scholars, a new critical consensus was in the making. The interesting thing about this new consensus, however, was that it recreated some of the conflicts at the heart of the modernist canonization: primarily, the tension between formalist and political readings of literature. As we have seen, the essence of the consensus between New Critics and New York intellectuals was precisely a renegotiation of formal and political aspects of literature. In the new theoretical climate, this opposition did not disappear without a trace. On the one hand, certain "post-structuralist" readers of Faulkner (representatives of what was eventually termed "New New Criticism") continued and redefined the formalist tradition by radicalizing its conclusions. On the other hand, we also witnessed an increasing politicization of literature. 
This politicization, however, seemed to reach conflicting conclusions. While some were busy reinventing Faulkner as a closet radical, others did the exact opposite and attacked him for his avowed conservatism. But what is important here is not so much the content of these political judgments but their form: it is radicalism as political form that became the object of investment. In other words, both Faulkner's detractors and supporters shared the essential belief of the postmodern consensus that progressive radicalism represents political value. A new standard of judgment emerged from the background of these debates: in order to excite our postmodern sensibilities, Faulkner should have been both aesthetically and politically a radical.

In order to explore in more detail the prehistory of this postmodern consensus, let us briefly compare a political and a formalist reading of Faulkner from the late seventies: Myra Jehlen's Class and Character in Faulkner's South (1976) and Gary Lee Stonum's Faulkner's Career: An Internal Literary History (1979). What concerns us here the most is the way the critique of the New Critical heritage is linked to the periodized canon in these two books. In spite of their differences, what is common to both Jehlen and Stonum is that they try to move beyond the New Critical heritage by reconciling its constitutive contradiction. Although later critics were quick to point out some of its shortcomings, Myra Jehlen's work has long been acknowledged as a pioneering political reading of Faulkner. To put it briefly, the crux of Jehlen's argument is to show that for Faulkner the class conflict between white planters and farmers takes precedence over the problem of race and his ideological ambivalence manifests itself on the level of form as well. In this regard, Jehlen turns against formalist critics who want to separate language from ideology and argues that for Faulkner "formal, linguistic problems in defining the Yoknapatawpha universe are ... inextricably ideological as well" (42). According to Jehlen, Faulkner's sympathies ultimately lie with the white aristocracy of the South, and although he is capable of sympathizing with the plight of poor white farmers and African Americans, he is ultimately unable to accept the logical conclusions his own position. Discussing Go Down, Moses, she explains the limitations of "Faulkner's ideology" in the following terms: "For although he seems to realize that the old racial ways can no loner work, he is unwilling to abandon them or even to reconsider the racist assumptions which they enacted" (I 2 I ). 
A brief comparison with Cowley's canonizing reading, however, will explain a lot about Jehlen's position. As we have seen above, even for Jehlen the question of form and ideology appears on the level of the "Yoknapatawpha universe." For her, the primary terrain of the interaction of form and ideology is the constitution of character-a conclusion not all critics would necessarily accept. Thus, her claim is not that Faulkner should not be reduced to a thematic unity but that this unity is ideological. Therefore, like Cowley, Jehlen is also aware of the formal shortcomings of Faulkner's novels, but rather then overwriting them by a thematic unity, she chooses to read them as signs of an ideological ambivalence (22-23). Thus, by substituting "ideological ambivalence" for "organic unity," Jehlen can bypass the internal contradiction of New Critical readings (the tension between organic unity and formal failure) as it is merely logical that ideological shortcomings should lead to formal complications. But when it comes to an evaluation of the late style, bypassing the New Critical contradiction through an ideological detour ultimately amounts to the reaffirmation of the conclusions of the New Critics. For example, this is how Jehlen speaks of Faulkner's "literary difficulties":

These [literary difficulties] appear especially in the very uneven Snopes trilogy ... written relatively late in Faulkner's career and thus coinciding with a slight but artistically significant drift to the political right. By this I refer, of course, not to a declared shift from left to right ... but to something more subtle having to do with the way he interpreted his material and with the degree of critical independence he maintained toward his subject. ... This aspect of his political views is especially important because it contributed to the definition of his characters. Faulkner's class bias was thus directly involved in the formal, most purely "artistic" aspects of his writing. (24-25)

In a certain sense, it is even easier for Jehlen to dismiss the late period than it was for Cowley, since she can also rely on the political argument according to which the late style is a reflection of an unwelcome political change. This is why it is important that Jehlen concurs with the traditional canon that Absalom, Absalom! is "Faulkner's best work, the high point of his career" (55), even if it turned out to be a dead end. In relation to this novel, the later works represent a regressive tendency as 
they deny its historical insights. Accordingly, the ideological attack on Faulkner and his liberal critics $(57-58)$ can make sense of a contradiction by supplementing it with a political argument, but it leaves the canon itself untouched.

As opposed to Jehlen's ideological reading, Gary Lee Stonum's primary objective is to reinvent the structure of Faulkner's oeuvre and move beyond the New Critical concept of "organic unity" by introducing the concept of "career." Rather than postulating a total unity, Stonum starts with the assumption of the contingent construction of the oeuvre based on an essential disunity. This lack of unity, however, cannot be turned into the absolute negation of the coherence of Faulkner's literary output. As Stonum explains: "The coherence is no simple unity; it cannot be grasped as a tidy linear unfolding, for example, or a process of steady, organic growth. Faulkner's development is not to be explained by a single, encompassing term for the cohesiveness of all his writings nor even by a set of terms that would establish the precise boundaries of his literary universe. Instead, it is a cumulative process of change in which temporary unities are continually dissolved and then reorganized as new work is produced" ( I $_{4}$ ). Stonum's relation to the formalist heritage is made clearer when he identifies the two schools against which he tries to define his own position. On the one hand, he speaks of the "exegetical" interpretations of New Critics who concentrate on individual works and authors (like Cleanth Brooks) who attempt to grasp Faulkner as a "whole." On the other hand, he distances himself from what he calls "theoretical poetics," a category that includes structuralist and post-structuralist critics who concentrate on structure and discourse and thereby move towards determining forces beyond the author's personality. Stonum's formalist compromise is to strike a balance between the two (New Criticism and its post-Structuralist critique): "The study of literary career thus differs from poetics in its assumption that the making of a career, rather than being a passive, involuntary, or wittingly resigned implementation of what literature allows, is a production more fully the writer's own. It likewise differs from exegetical criticism in not positing some autonomous, originating figure who directs the career with complete freedom" (26). Thus, the new model that emerges from this critique of New Critical canon formation is that of an "open system": Faulkner's literary career is simultaneously programmed and capable of re-programming itself. 
If the contradiction at the heart of Faulkner's New Critical canonization was the tension between a hypostatized organic unity and the effective reality of a disunited canon, we find that Stonum's redefinition of the structure of the oeuvre questions this "organic unity" but reaffirms the periodized canon. The difficulty of Stonum's enterprise is to maintain the coherence of the oeuvre without inventing yet another "single, encompassing term for the cohesiveness of all [of Faulkner's] writings." For Stonum does retain a master trope: "arrested motion." While the myth of Yoknapatawpha only provides continuity on the level of subject matter, according to Stonum, the concept of "arrested motion implies specifications of method, form, theme, and purpose" (33). In spite of Stonum's professed goal to prove that "Faulkner is . . not a static essence but a process of transformation" (2OI), his choice to organize his readings in relation to a master trope (something that remains the same through this process of transformation) necessarily results in a return to the rhetoric of periodization. Since Stonum wants to show the successive changes of the same principle, he ends up separating coherent units within the persistence of the same. The four phases-which correspond to four different ways of "arresting motion" in art-are the following: the first is Faulkner's poetry and early fiction in thrall of pure aesthetics; the second is "Faulkner's first mature fiction"; the third is the works of the late ' 30 ; and the last phase is the I940s and I950s. He dates the beginning of the last phase with the appearance of The Hamlet ( 1940) and considers the Snopes Trilogy to be its highest achievement. Unlike the previous three, the last phase "attempts to comprise all of what has gone before and, most importantly, to find a new level of organization for it rather than to dismantle the assumptions necessary to Absalom, Absalom!" (154) As he simultaneously declares the failure of A Fable (i6o) and celebrates the virtues of the Snopes trilogy, he effectively recreates the New Critical canon without its internal tension. The critique of organic unity—in Stonum's case at least—does not necessarily entail a critique of the canon.

On the basis of these two earlier examples, we can now briefly outline some of the defining characteristics of the postmodern consensus. What I would like to show here is that most postmodern critics adopted one of two alternative strategies in their re-canonization of Faulkner. Some basically followed the path taken by Jehlen and Stonum and tried to reconcile the internal contradiction of New Critical readings 
by interpreting this tension as the sign of the earlier critics' inability to cope with the postmodern impulse in Faulkner. Others, however, chose the opposite path and, starting from similar assumptions, deliberately reversed the modernist canon. First of all, we have to note that these readings (unlike the modernist consensus which tried to equate formal innovation with moderate politics) represent an attempt to link formal and political radicalism. The formalist postmodern strategy was characterized by a tendency to discover in Faulkner's novels a postmodernist impulse which was often interpreted as a radicalization of modernist aesthetics. The most influential formulation of this thesis is to be found in Brian McHale's Postmodernist Fiction which argued that Absalom, Absalom! represents a move beyond modernist aesthetics (Io). 9 Similarly, to quote a more recent example, Doreen Fowler considers Absalom, Absalom! to be the "postmodern turn" in Faulkner's oeuvre, since in comparison with The Sound and the Fury it managed to reach a higher level of self-reflexivity and thereby successfully deconstructed patriarchy. According to Fowler, The Sound and the Fury "is demonstrably subversive in both form and content," but there is "a crucial lapse in the novel's self-reflexivity" (97). In other words, the distance between modernism and postmodernism is to be measured in degrees of subversion and self-reflexivity. This type of reading makes a full re-appropriation of the original Faulkner canon possible by locating the postmodern at the heart of Faulkner's modernism. In a certain sense, we witness here yet another substitution similar to the ones performed by Jehlen and Stonum. This time, however, "organic unity" is not replaced by "ideological ambivalence" or "arrested motion" but by the newly discovered "postmodern turn" which provides a consistency to the canon that goes beyond the failures of earlier formalist critics.

Instead of reinventing the major works, the other postmodern strategy that I want to call attention to reinterprets the status of the minor works by exploring the reasons why they fell outside the modernist consensus. In this regard, what makes Richard Moreland's book, Faulkner and Modernism (1990), an interesting case study is precisely the fact that he rediscovers the "late works" as attempts to move beyond Faulkner's modernist failures. What was considered to be a failure of the late style, namely repetition, is now reinterpreted as the very essence of Faulkner's art which therefore allows for a critical judgment of the oeuvre. Putting aside the question of the validity of Moreland's cri- 
tique of modernism, we can clearly observe that this attack still works within the framework of the periodized canon only reconsiders the last phase as the quasi-teleological move towards the next stage of literary history (a nascent postmodernism) rather than a decline from triumphant modernism. The late period is no longer a retreat but a victorious advance. In other words, one method of the postmodern canonization was to recast the central division of the periodized canon in terms of the modernist/postmodernist divide.

Faulkner's redefinition as a postmodernist author was almost always accompanied by a positive political judgment. André Bleikasten, however, in a polemical piece directed against the "new ideologues" of the late-eighties and the early-nineties, warned us that the move beyond formalism is not without its own dangerous excesses. Bleikasten rejected - in no equivocal terms - the tendency that turns Faulkner into "a writer with strong political commitments on the left" (I4) through the revaluation of the late style. I will quote here one of Bleikasten's primary targets, Joseph R. Urgo's Faulkner's Apocrypha ( I 989), to illustrate this turn toward political and aesthetic radicalism through a revaluation of the late works: "The radicalism of his apocrypha has been muted partially because of the personal image he cultivated in the I950s, a nonconfrontational, cordial, and rather self-indulgent style of Nobel Laureate. His radicalism has been further muted by a specific reluctance on the part of critics to address issues raised in his most ambitious projects" (4). I would like to juxtapose to this statement Noel Polk's analysis of the modernist consensus, since he gave us an excellent description of the way the domesticated political image of the late Faulkner was projected upon the early Faulkner to save him from charges of nihilism, while the image of this domesticated modernist was turned against the later Faulkner to disqualify his artistic achievements (302-3). In other words, we can trace here a symmetrical reversal of categories. The modernist consensus projected the politics of the late style onto the formal innovations of the major period in order to disqualify the late works, while the postmodern consensus evoked the image of "the radical postmodernist" through projecting the dynamics of earlier formal innovations onto the politics of the late style. In other terms, in the case of the modernist Faulkner the political stance was formalized, since "radical" formal innovation was given a moderate political content; while in the case of the postmodern Faulkner, a formal aspect was politicized, since 
Faulkner's deviation from modernist formal standards was given a progressive political content. ${ }^{10}$

The revaluation of the late period, however, proved to be a much more difficult task than it had been first expected, and it is still at the forefront of the critical debates today. For example, surveying the critical output of the Faulkner industry in I 999, Philip Cohen and Joseph R. Urgo complained that "Faulkner studies continues to suffer from critical inattention to the later works, leaving some critics without a fully informed understanding of his contributions to 2oth-century literary and intellectual history" ( 79 ). So, the question remains: What can we conclude from the insight that the "late style" is not a consequence but rather a condition of Faulkner's canonization? First and foremost, it becomes clear that contrary to the generally accepted narrative of Faulkner's canonization, it is not enough to say that the making of Faulkner's reputation was based on the consideration of his works as a whole and the perception of a unity within this whole. Quite to the contrary, the perception of the thematic unity was based on the identification of a lack of unity within the whole. The most effective way of formalizing this disunity was the creation of the Faulkner canon. This is why unity is the privilege of the canonized works only. To put it differently, while the critical invention of unity served the purpose of hiding an essential lack of unity, the creation of the category of the late phase made it possible to maintain this lack of unity although in a displaced form as an issue of periodization.

So, when it comes to an evaluation of the late phase, a simple reversal of categories (the elevation of the late phase over the major period) or the complete abandonment of the discussion of internal differences in the oeuvre appear to be equally misguided. Rather, I would insist that the "late style" is the first consensual critical name given to the very condition (rather than the actual reason) of Faulkner's canonization which is the lack of final unity of the cultural entity known as "Faulkner." If the late style names the condition of Faulkner's canonization, it would be rather difficult to get rid of such a category altogether. What we can do is articulate this condition, Faulkner's internal difference, in ways different from the inherited category of the late style. Such a rearticulation would imply that from the initial recognition that Faulkner is not "one," we do not automatically rush to the conclusion that Faulkner is simply "two." Before we get lost in a jubilant arithmetic 
of an infinite number of Faulkners, however, I want to point out that the stake of such an inquiry is obviously not the discovery of the correct number of Faulkners, but the confrontation with the self-evident point that Faulkner is simply not "Faulkner."

SUNY-Buffalo

\section{NOTES}

I. Another significant attempt to assess Faulkner's reception can be found in O. B. Emerson. I concentrate on Schwartz's work because Emerson merely classifies the different types of early Faulkner criticism, while Schwartz also tries to explain the changes he identifies.

2. As an example of the first strategy I would refer to Fowler's article which argues that Absalom, Absalom! is essentially a postmodern work. For the second strategy, which reinterprets the late style as a move beyond modernism, see Moreland.

3. For a collection of contemporary reviews and a list of further references, see Inge's selections. For an extensive description of this early reception, see Emerson.

4. See Skei's article on the concept of "early Faulkner." For discussions of the "late style," see for example Carothers' and Millgate's articles.

5. All of the early Faulkner commentators who made an assessment of the whole oeuvre were of roughly the same opinion. My reading is based on books by the following: Miner, Coughlan, O'Connor, Vickery, Slatoff, Hoffman, Howe, Millgate, Brooks, Swiggart, and Hoffman and Vickery. For a brief analysis of the early anthologization of Faulkner's work see Millgate's "Defining Moment." For recent assessments of the concept of "career" in Faulkner criticism, see Skei's, Wittenberg's, and Zender's articles in Faulkner at 100.

6. In more specific terms, Schwartz formulates this duplicity in the following way: "What must be discovered, in other words, was a great literature rooted in regional consciousness, but one that also transcended provincial nationalism to achieve universality .... After the war, Faulkner would be read in terms of both the traditionalism of Eliot, Tate, and the New Critics and the revolutionary modernism of the New York intellectuals" (94).

7. Brooks himself is much closer to realizing Millgate's ideal. The magnum opus of the formalist response to Faulkner was, of course, Brooks' Yoknapatawpha Country from the same year as Millgate's Achievement, and Brooks very explicitly works with a concept of "major works" that can be clearly distinguished from the minor ones.

8. Without trying to provide an exhaustive list, I will merely list some of the major critics of this second wave of Faulkner criticism: Irwin, Bleikasten, Jehlen, Kartiganer, Polk, and Matthews. 
9. This strategy was categorically rejected by Ihab Hassan.

ı. Quite interestingly, Zender's book seems to be outlining a new consensus. In its preface, Zender describes himself as a product of the ig6os and expresses his dissatisfaction with the postmodern Faulkner. Nevertheless, he admits that he did learn certain things from postmodern scholars and proposes a critical position that could interpreted as a compromise between the modernist and the postmodern consensus: "The book acknowledges the need—indeed, the desirability—of politicizing the reading process and of decentering the canon, but it seeks to articulate a middle-of-the-road alternative to the dominant postmodern approach to both of these developments" (xiv).

\section{WORKS CITED}

Aiken, Conrad. "William Faulkner: The Novel as Form." Atlantic Monthly Nov. I939: 650-54.

Bleikasten, André. The Most Splendid Failure: Faulkner's The Sound and the Fury. Bloomington: Indiana University Press, I 976.

- "Faulkner and the New Ideologues." Faulkner and Ideology. Ed. Donald M. Kartiganer and Ann J. Abadie. Jackson: University Press of Mississippi, I 995. $3^{-2 \mathrm{I}}$.

Brooks, Cleanth. William Faulkner: The Yoknapatawpha Country. I963. Baton Rouge: Louisiana State University Press, I 990.

—. William Faulkner: Towards Yoknapatawpha and Beyond. 1978. Baton Rouge: Louisiana State University Press, I 990.

Carothers, James E. "The Rhetoric of Faulkner's Later Fiction, and of Its Critics." Faulkner's Discourse: An International Symposium. Ed. Lothar Hönnighausen. Tübingen: Max Niemeyer Verlag, I988. 263-70.

Cohen, Philip and Joseph R. Urgo. "Faulkner." American Literary Scholarship: An Annual. 1999. I 79-200.

Coughlan, Robert. The Private World of William Faulkner. New York: Avon Book Division, I953.

Cowley, Malcolm. "William Faulkner Revisited." Saturday Review April I4, I945: I3-I6.

. "Introduction." The Portable Faulkner. 1946. Revised and Expanded Edition. New York: Viking, I98I. vii-xxxiv.

Dimitri, Carl. "Go Down, Moses and Intruder in the Dust: From Negative to Positive Liberty." The Faulkner Journal I 9. I (2003): I I-26.

Duval, John N. and Ann J. Abadie, eds. Faulkner and Postmodernism. Jackson: University Press of Mississippi, 2002.

Emerson, O. B. Faulkner's Early Literary Reputation in America. Ann Arbor: UMI Research Press, I984.

Fowler, Doreen. "Revising The Sound and the Fury: Absalom, Absalom! and Faulkner's Postmodern Turn.” Duval and Abadie 95-108. 
Hassan, Ihab. "The Privations of Postmodernism: Faulkner as Exemplar (A Meditation in Ten Parts)." Duval and Abadie I-I8.

Hoffman, Frederick J. William Faulkner. New York: Twayne Publishers, I 966.

Hoffman, Frederick J., and Olga Vickery. Two Decades of Criticism. East Lansing: Michigan State College Press, I95I.

- Three Decades of Criticism. East Lansing: Michigan State College Press, I960.

Howe, Irving. William Faulkner: A Critical Study. New York: Vintage, I952.

Inge, Thomas. William Faulkner: The Contemporary Reviews. New York: Cambridge University Press, I995.

Irwin, John T. Doubling and Incest/Repetition and Revenge: A Speculative Reading of Faulkner. Baltimore: John Hopkins University Press, I975.

Jehlen, Myra. Class and Character in Faulkner's South. New York: Columbia University Press, I976.

Kartiganer, Donald M. The Fragile Thread: The Meaning of Form in Faulkner's Novel. Amherst: University of Massachusetts Press, I979.

Kartiganer, Donald M., and Ann J. Abadie, eds. Faulkner at roo: Retrospect and Prospect. Jackson: University Press of Mississippi, 2000.

Matthews, John T. The Play of Faulkner's Language. Ithaca: Cornell University Press, 1982.

Maclachlan, John Miller. "William Faulkner and the Southern Folk." Southern Folklore Quarterly 9 (1945): I 53-67.

McHale, Brian. Postmodernist Fiction. London: Routledge, I 99 I.

Millgate, Michael. The Achievement of William Faulkner. New York: Random House, I966.

. "Defining Moment: The Portable Faulkner Revisited." Kartiganer and Abadie 26-44.

. "Faulkner: Is There a 'Late Style'?" Faulkner's Discourse: An International Symposium. Ed. Lothar Hönnighausen. Tübingen: Max Niemeyer Verlag, I988. $27 \mathrm{I}-75$.

—. Faulkner's Place. Athens: University of Georgia Press, I 997. . William Faulkner. New York: Grove, ig6r.

Miner, Ward L. The World of William Faulkner. Durham: Duke University Press, 1952.

Moreland, Richard. Faulkner and Modernism. Madison: University of Wisconsin Press, I990.

O'Connor, William Van. The Tangled Fire of William Faulkner. Minneapolis: University of Minnesota Press, I954.

O’Donnell, George Marion. "Faulkner's Mythology." Kenyon Review I (I939): 285-99.

Polk, Noel. Faulkner's Requiem for a Nun: A Critical Study. Pub data needed. I98I. 
"'Polysyllabic and Verbless Patriotic Nonsense': Faulkner at MidcenturyHis and Ours." Faulkner and Ideology. Ed. Donald M. Kartiganer and Ann J. Abadie. Jackson: University Press of Mississippi, I995. 297-328.

Ramsey, D. Matthew. "'Lifting the Fog': Faulkners, Reputations and The Story of Temple Drake." Faulkner Journal I6.I-2 (Fall 2000/Spring 200I ): 7-33.

Schwartz, Lawrence H. Creating Faulkner's Reputation: The Politics of Modern Literary Criticism. Knoxville: University of Tennessee Press, I988.

Skei, Hans H. "'Faulkner Before Faulkner': The Early Career As a Construction in Retrospect." Kartiganer and Abadie 93-99.

Slatoff, Walter J. Quest for Failure: A Study of William Faulkner. Ithaca: Cornell University Press, i960.

Starke, Aubrey. "An American Comedy: An Introduction to a Bibliography of Willaim Faulkner." Colophon ig (Jan. I935): n.p.

Stonum, Gary Lee. Faulkner's Career: An Internal Literary History. Ithaca: Cornell University Press, I979.

Swiggart, Peter. The Art of Faulkner's Novels. Austin: University of Texas Press, I962.

Vickery, Olga. The Novels of William Faulkner. Baton Rouge: Louisiana State University Press, 1964.

Wittemberg, Judith Bryant. "Absalom, Absalom! and the Challenges of Career Design." Kartiganer and Abadie ıоo-8.

Zender, Karl F. "Faulkner's Career: Concept and Practice." Kartiganer and Abadie Io9-19.

. Faulkner and the Politics of Reading. Baton Rouge: Louisiana State University Press, 2002.

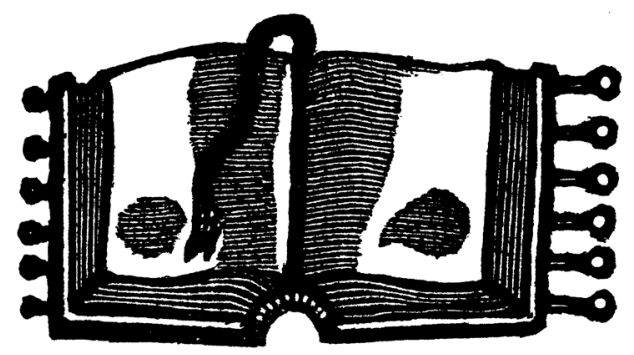

